\title{
BASIC DETERMINANTS OF LEGAL CULTURE FORMING OF FUTURE QUALIFIED SEAFOOD WORKERS
}

\author{
Yuliia Yezhokina, \\ Postgraduate student at the Institute of Vocational Education and Training of NAES of Ukraine \\ http://orcid.org/0000-0002-3415-1064 \\ e-mail: julianka2008@ukr.net
}

\begin{abstract}
The article substantiates the main pedagogical conditions of purposeful formation of the legal culture of future qualified sailors working in VET schools. The formation of the legal culture of future seamen workers, first of all, is aimed at mastering modern legal knowledge of students, in particular in the field of international maritime law, formation of their legal awareness, ability to successfully resolve future professional and legal situations, readiness to constantly replenish the amount of legal knowledge in self-education activities. Today it is especially relevant for graduates of vocational education institutions of the maritime profile: domestic shipping is changing substantially, changing conditions of work of the floating crew, in particular, on international vessels.

The leading idea of the research characterizes the position that the legal culture, legal awareness, legal behavior, in particular future qualified skilled workers, should be purposefully formed, developed.

In the work of the means of expert evaluation revealed a number of factors that have the greatest impact on the formation of the legal culture of future skilled seamen workers, in particular: innovative pedagogical technologies; the content of the professional training of future seamen workers; modern means (including IT technologies) of vocational training; informational and educational environment of the institution of VET schools; pedagogical integration; self-education cognitive and legal activity of the student; effective methods of mastering students with legal knowledge and skills; vocational and pedagogical competence of teachers involved in the training program of seamen; experience of professional and legal behavior; motivation of students to master professional-legal knowledge; diagnostics, evaluation and management of the formation of the legal culture of students.

According to the results of the factor analysis, the following basic pedagogical conditions were substantiated: purposeful formation of the needs of students in the professional legal knowledge; application of innovative pedagogical technologies in professional legal training of seamen's workers; organization of productive selfeducation cognitive and legal activity of students; establishment of the elective course "Legal Culture of a Modern Seaman" in the educational process of VET schools.
\end{abstract}

Keywords: professional education, legal culture, future qualified worker-sailor, international maritime law, legal awareness.

Introduction. The tendencies of social and economic development of the Ukrainian society, having been investigated in recent years, are convincing that the formation of the citizens' legal culture, their high legal awareness is the dominant vector of modernization process. This, in turn, requires a thorough vocational and legal training of skilled workers in all sectors of production, seafarers in particular.

Since shipping has undergone significant changes over the past decade, the problem is especially relevant: the new generation of ships have appeared, a significant part of production processes with new forms of work organization have been updated, new technologies of 
navigation security in particular have been introduced. A considerable number of the graduates of domestic vocational maritime institutions work on foreign maritime vessels. According to the Labor Market Survey, the World Trade Maritime Fleet (Manpower Report), today Ukraine assumes the sixth position in the rankings among the maritime labor supply countries (International Maritime Organization, 2017).

Ukraine is a member of the International Maritime Organization (IMO) and has signed major international regulations on maritime safety, in particular the International Convention on Standards of Training, Certification and Watchkeeping for Seafarers, 1978, as amended (Manila Amendment, 2012). The implementation of the agreements, codes and recommendations of this international organization into the legislative framework of Ukraine obliges the management of maritime transport to make up the crews with highly proficient seafarers, who could ensure the safe operation of ships, the preservation of cargoes, and who obtained high professional (vocational) and legal training, in the field of international maritime law in paticular.

Materials and methods. The problem of the formation of the prospective skilled seafarers' and proficient specialists' legal culture has been investigated in scientific research of teachers, philosophers, lawyers. As a component of professional culture, the legal culture of the future specialist has been developed by V.Grinev, I.Zyazun, V.Lozova, M.Kozyar, D.Kovalenko, M.Fitsula and others. Scientific aspect of legal culture formation by means of educational activities was the subject of the research carried out by such scholars as: G.Vasyanovich, M.Gorodysky, I.Darmansky, V.Kopeychikov, V.Kotyuk, O.Rem. The legal culture of personality as a result of the mechanisms of legal education has been investigated by I.Gryaznov, N.Luginova, T.Osipova, V.Rayko, G.Yavorskaya. In a number of papers written by scholars-lawyers (O.Skakun, S.Slivka, V.Tsarenko, V.Yarmolenko) the peculiarities of the development of the professional legal culture of the law enforcement officers has been determined.

At the same time, there are very few works in which the scientific aspects of the legal culture formation of the prospective skilled seafarers have been investigated, this fact substantially actualizes the problem and determines the search for answers to the questions: what factors and pedagogical conditions should we provide for effective pedagogical actions in order to develop the given component of the general professional culture of the prospective skilled seafarers to sufficient levels?

For the solution of the given tasks the theoretical methods have been used (analysis of scientific resources, study of the normative documents requirements on the subject of the research, analysis of educational programs - in order to determine the state of the problem of the research and to define the directions of scientific search, comparison - in order to study various scientific approaches to the solution of the problems, analysis and synthesis - in order to establish cause-and-effect relationships between factors and conditions; empirical (observations, expert evaluations) - in order to determine the significance of factors, as well as methods of mathematical statistics (for summarizing the results obtained, their representation in tables and determining the coefficient of concordation).

Whereas the foregoing statements the purpose of the article is to substantiate the pedagogical conditions of purposeful formation of the students' legal culture at the Vocational Education Institutions of the maritime profile.

Results and discussions. Scientists unanimously admit that the legal culture, legal awareness, legal behavior of prospective skilled seafarers in particular, should be purposefully formed, developed. In order to provide the necessary scientific and methodological support for the given process, it is necessary to determine and theoretically substantiate the leading determinants that must be considered and provided first of all. The point is, first of all, about factors (circumstances, factors, causes, etc.), which we must determine with the results of scientific research.

It would not be out of place to point out that in psychological and pedagogical studies there is no unity of thoughts among scientists about the essence of such concepts as "factor", "condition", as their researchers often do not distinguish them. Such approaches can be found not only in scientific and pedagogical works, but in reference literature as well. In particular, in the "Great Explanatory Dictionary of Contemporary Ukrainian Language" (Bousel, ed., 2009), the "condition" is interpreted as a necessary circumstance that makes possible the implementation, creation, formation of something or facilitates for some reason. In turn, the notion of "factor" is defined as a condition, the driving force of any process, phenomenon; factor.

In our study, following P. Luzan (2004), V. Kruchek (2003), I. Mosya (2013), we determine factors and conditions in such way: pedagogical factors as the driving forces of the formation of the legal culture of the individual, having potential opportunities, become the driving forces of the process due to the created conditions (circumstances), which ensure their effectiveness by appropriate means.

At the first stage of the experimental work, the task was set: to determine the totality of factors that most significantly influenced the formation of the legal 
culture of future skilled seafarers in the conditions of the educational process of the professional (vocational) education schools by means of a broad pilot study. For this purpose, the questionnaire was proposed to the respondents (pedagogical personnel of the professional (vocational) education schools of maritime profile, 29 participants), which suggested to indicate the factors of active, effective formation of the students' legal culture. In addition, we maintained that the instructions given to the respondents contained the explanation of the essence of legal culture as a phenomenon, the main content components of this integrative characteristic of the prospective skilled seafarers were listed as well.

According to the results of the survey conducted among the pedagogical staff, 11 factors were most often identified by respondents, in particular: innovative pedagogical technologies; the content of the professional and legal training of the prospective skilled seafarers; modern means (including IT technologies) of vocational and legal training; informational and educational environment of the professional (vocational) education schools; pedagogical integration; self-educational, cognitivelegal activities of the student; effective methods of mastering legal knowledge and skills by the students; professional and pedagogical competence of the teachers involved in the training program for seafarers; experience of professional and legal behavior; students' motivation to master vocational-legal knowledge; diagnostics, evaluation and management of the students' legal culture formation.
It's significant, that in the given list, the teachers pointed out the factors that could potentially impact on effectiveness of the legal culture formation of future skilled seafarers. Naturally, among these determinants there are the main, the most significant ones, which we must consider primarily.

To determine the validity of these factors an expert evaluation was conducted. In the expert letter to the respondents (19 faculty experts) it was suggested that these factors had to be ranked according to their importance in shaping the legal culture of prospective skilled seafarers. It should be noted, that in order to determine the reliability of the results before the expert letter, a control factor "Self-educational cognitive-legal activity of the student" had been introduced. It is not difficult to notice that the informational and educational environment is somewhat correlated with the self-education activities of future seafarers, and therefore we should predict that providing the validity of the method, the sum of the ranks of these two factors should not differ significantly. Based on the results of the experts' ranking of the factors of the formation of the legal culture of prospectiveskilled seafarers, Table 1 was completed and the ranked sums of factors, their average values and places in the overall ranking system were determined.

It is worth noting that, as we hadpredicted, the factors "Self-educational cognitive-legal activities of the student" and "Information and educational environment of the professional (vocational) education schools" scored approximately the same sum of ranks -94.0 and 93.5 respectively. This is evidence of the objectivity and reliability of the research results.

\section{Table 1}

\section{Results of experts' ranking of factors forming the legal culture of prospective seafarers}

\begin{tabular}{|c|c|c|c|c|}
\hline \multirow[t]{2}{*}{ № } & \multirow[t]{2}{*}{ Factor } & \multicolumn{3}{|c|}{ Validity of factor } \\
\hline & & Sum of ranks & Average rank & Place \\
\hline 1 & Innovative pedagogical technologies & 45,5 & 2,34 & II \\
\hline 2 & Self-educational cognitive-legal activities of a student. & 94,0 & 4,94 & $\mathrm{~V}$ \\
\hline 3 & $\begin{array}{l}\text { Modern means (including IT technologies) of vocational } \\
\text { and legal training }\end{array}$ & 203 & 10,68 & $\mathrm{XI}$ \\
\hline 4 & $\begin{array}{l}\text { Informational and educational environment of the professional } \\
\text { (vocational) education schools }\end{array}$ & 93,5 & 4,92 & IV \\
\hline 5 & Pedagogical integration & 170,5 & 8,97 & $\mathrm{X}$ \\
\hline 6 & $\begin{array}{l}\text { Content of the professional and legal training of the prospective } \\
\text { seafarers }\end{array}$ & 144 & 7,57 & VIII \\
\hline 7 & $\begin{array}{l}\text { Effective methods of mastering legal knowledge and skills by } \\
\text { the students }\end{array}$ & 61,5 & 3,23 & III \\
\hline 8 & $\begin{array}{l}\text { Professional and pedagogical competence of the teachers } \\
\text { involved in the training program for seafarers. }\end{array}$ & 106,5 & 5,60 & VI \\
\hline 9 & Experience of professional and legal behavior & 140,5 & 7,39 & VII \\
\hline 10 & Students' motivation to master professional-legal knowledge & 36,5 & 1,92 & $\mathrm{I}$ \\
\hline 11 & $\begin{array}{l}\text { Diagnostics, evaluation and management of the students' } \\
\text { legal culture formation }\end{array}$ & 158,5 & 8,34 & IX \\
\hline
\end{tabular}


To elaborate objective conclusions based on the results of an expert evaluation of the factors shaping the legal culture of the prospective skilled seafarers, it was necessary to find out information about the unity of opinions of the expert group members. We see that such a procedure in conjunction with the verification of the accuracy of the matrix filling determines the validity of both the devices and the method of expert evaluation.

For this purpose, the coefficient of concordation , proposed by M. Candell and B. Smith, was used. Without going into the description of the known method of determining the coefficient of concordation, we state that in our research it is equal to 0.59 (at a significance level of 0.05 , determined by the Pearson statistical criterion) (Glass, Stanley, 1976).

Thus, the performed statistical calculations confirm the consistency of experts' opinions in determining the validity of factors and the reliability of the results of experts' evaluation.

Relying on the results of the statistical analysis, we can state that the most influential pedagogical factors in the formation of the students' legal culture are: motivation to master the professional and legal knowledge; innovative pedagogical technologies; effective methods of mastering legal knowledge and skills; informational and educational environment of the professional (vocational) education schools; selfeducational, cognitive-legal activities of the student; diagnostics, evaluation and management of the students' legal culture development; professional and pedagogical competence of the teachers involved in the training program for seafarers.

Applying the inductive method of establishing cause-and-effect relationships, we define the main pedagogical conditions that can transform experimentally determined factors into real causes of the formation of the legal culture of future skilled seafarers.

It's remarkable that the motivation of students to master professional and legal knowledge is determined by experts as a factor that primarily affects the formation of the students' legal culture. The scientists, and not coincidently, associate the motivation with the activity of the individual, with the driving forces of individual's behavior and activities.

First of all, it is about motives and needs as psychological content, which stimulates the students' aspiration for mastering knowledge, skills, experience and legal information in particular. At the same time, we define the motives as impulsive cause of the person's actions and behavior (the one that pushes for action); the need is interpreted as "the state of a living organism, a human individual, a social group or society as a whole, which expresses the need for something ... and is the driving force of their activity ... The pedagogical value of needs derives from their role in the development of personality" (Goncharenko, 1997, p. 226).

It should be stated that classical psychology has proved a close connection of needs and motives: the motives of behavior and activity arise from the realization of needs. At the same time, stimulation plays an extremely important role in the first initial stages of studying. It should be considered that we explain the stimulus as the internal or external factor causing the reaction, the action of a person (encouragement, perspective, game, ritual, tradition, didactic method, positive example, etc.). The mechanism of the development of the studying motive can be modeled as follows: the needs of a student "are encountered"with stimuli (the "objectivation"of the needs through the stimulus is being carried out) transfiguration, transformation of the need into a motive and its awareness - further development of needs and motives at the expense of learning - the development of cognitive activity of the individual.

In our opinion, future proficient seafarers mastering professional and legal knowledge must be initiated with pedagogical stimulation, which later should be deliberately replaced by motives-interests arising on the basis of students' intellectual satisfaction with positive results. In the future, for the development of students' cognitive-legal interests, it will be necessary to implement the following methodical techniques: the creation of problem situations; involvement in the project activity; demonstration of examples vital for a seafarer, especially by Internet means - which require students' productive-creative and cognitive actions.

On the basis of the foregoing, we define the first pedagogical condition for the formation of the legal culture of future skilled seafarers: the purposeful formation of the students' need for professional and legal knowledge.

It's reasonable that the formation of professionallegal knowledge, moral and legal characteristics, motivational-value orientations of the individual is carried out on the background of the implementation of the competent approach to the training of seafarers.

The indicated methodological educational conception envisages the achievement of the goals of competence-oriented training by means of pedagogical technologies. Pedagogical technologies can be determined as one of the directions of pedagogical science, developed to ensure the achievement of planned tasks, to increase the effectiveness of pedagogical interaction, to guarantee a high level of educational results.

Among modern pedagogical technologies, researchers single out the following varieties: problem learning; gaming; differentiated teaching; informational personally oriented training; developing training; collective learning method; development of 
critical thinking; program training; interactive learning; modular training; collective creative education; distance learning, etc.

Both traditional and innovative teaching methods are used in pedagogical practice. It's reasonable, that traditional as well as innovative teaching methods have some advantages and disadvantages. It is appropriate to distinguish such advantages of traditional teaching methods as: organizational accuracy of the pedagogical process; constant, purposeful ideological and emotional influence of the teacher's personality on the students; optimal resources distribution at total training; arranged, logically structured presentation of teaching material; orientation on the development of the mental processes of the student's personality (memory, thinking, attention, imagination, etc.); availability of instructional content; taking into account age and individual characteristics of students; the thoroughly planned ("bookish") students' knowledge, etc.

Disadvantages include: predominance of reproductive, algorithmic teaching methods; dominance of theoretical knowledge in the structure of graduates' qualification; improper orientation of the educational process to the development of the student's personality creative potential; domination of frontal forms of the training organization to the detriment of a person-oriented approach; predominance of subjectobject relationships in pedagogical interaction, etc.

Innovative pedagogical technologies significantly eliminate the disadvantages of the customary educational process organization. They are purposeful, systematic and consistent practical implementing original, innovative methods, methods of pedagogical actions and means for changing the style of thinking and behavior of participants in pedagogical interaction, motivating students to self-improvement, selfdevelopment, and therefore contribute to improving the quality and effectiveness of the educational process.

It is worth agreeing with the scholars that the following are relevant today: pedagogical technology of critical thinking; teaching methods as a research; integral pedagogical technology; technology of developmental training; technology of forming a creative personality; case technology; project technology; group training technology, etc. To complete the coverage of this aspect, we establish that innovation activity is specific and rather complex, requiring special knowledge, skills and abilities. Therefore, the implementation of innovations is impossible without a teacher-researcher who has systemic thinking, developed ability to creative work, formed and conscious readiness not only to be involved in innovation processes, but also to be their initiator.

Thus, the implementation of innovative pedagogical technologies in the professional legal training of seafarers we distinguish by the second pedagogical condition for the purposeful formation of the legal culture of prospective skilled seafarers.

Regarding the intensity of technological changes, dynamic innovation processes and constant information updating in all spheres of public life and production, it is evident that no institution of professional (vocational) education can provide students with the knowledge sufficient for an effective activity in professional life.

Considering the aforesaid, there is a need for creating and implementing in professional (vocational) education schools the mechanisms of development of students' ability to effective self-education enabling them to work with different sources of knowledge and continuously develop their own intellectual potential, since under current conditions experienced worker must constantly improve his/her professional level and gain new knowledge and skills. It's a prerequisite for maintaining an adequate level of own competitiveness at the labor market, where the professional requirements to the specialists are constantly increasing. Therefore, one of the foreground tasks of modern education is to develop students' independence, ability to self-organization, self-development and selfeducation.

Most scholars (N.Bukhlova, B.Vovk, N.Kubrakova, I.Mosya, N.Polovnikova, V.Sknar, A.Trofimenko, etc.) demonstrate the unity of thoughts stating that selfeducation is acquired in the process of independent work without systematic course of study at an educational institution. Self-education is an integral part of systematic study, it promotes the deepening, expansion and strengthening of mastering the programme knowledge.

While researching, we concluded that the driving force of self-education is the internal motivation of the student. Self-education activities can be considered as the upper level of personality's development as a subject of educational and cognitive activities. At the same time, the effectiveness and results of the implementation of self-education are more important in the personal and social sense.

According to our study, the effectiveness of students' self-education activity depends on the correctness of its organization at the professional (vocational) education schools. It is precisely the systematic work of the teacher aimed at organizing an effective students' self-education activity and developing their self-educational competence, contributes to the education of a personality ready for self-education through life, able to solve independently his/her personal as well as global problems, capable of creativity, self-development and self-realization.

Based on the foregoing, we define the third pedagogical condition for the purposeful formation of the legal culture of prospective skilled seafarers: organizing students' productive self-educational cognitive and legal activities. 
Legislative regulations, particularly in the field of maritime law, are constantly changing, new regulations, requirements and procedures are emerging. That is why it is extremely important to update constantly the teaching materials, providing the content of education with modern knowledge that they could implement in their professional activities from the first days of their work. Unfortunately, curricula and programs don't respond to ongoing changes in the current legislation, therefore, there is a need to implement additional forms of study into the educational process.

Currently, special workshops, studies, special courses, electives have increased the efficiency of educational activities due to individualization, wide variation in the content of education, are becoming increasingly popular. For example, electives has occupied an important place in the modern educational process, since they positively influence the formation of students' interests, cognitive activity, and facilitate the development of their creative attitude to independent work.

In our opinion, some scientists (N.Ostroverkha, S.Palchevsky, M.Fitsula, V.Chaika, L.Yakimenko, etc.) emphasize rightly that elective courses are aimed at enhancing the students' substantive knowledge of the courses, sections or themes of the subject taking into account their interests and desires. This is one of the effective forms of differentiated teaching intended for improving students' cognitive interests, intellectual abilities and forming students' vocational guidance. Compared with classroom studies, elective courses provide a high level of students' creative abilities. Search and research methods of teaching, project method in particular, heuristic method, etc. can be applied more widely and effectively.

Taking the above-mentioned into account, we must conclude that the implementation of the elective course "Contemporary Seafarer's Legal Culture" into training of the prospective skilled seafarers, firstly, will ensure the ability to resolve successfully the tasks: to supplement and deepen the legal knowledge that students acquire mastering legal disciplines, thereby expanding their basic legal competence; to increase students' professionally oriented interest for the future professional activities; to expand students' interdisciplinary skills and interests through the integration of legal knowledge with the knowledge of professional-theoretical and vocational-practical training; to complete practice-oriented subject competence and career orientation.

Secondly, the implementation of such additional form of professional and legal training for future proficient seafarers makes it possible to apply a complex of productive methods of mastering legal knowledge, extends the content of legal disciplines to the modern knowledge component, and should contribute to the effective development of the students' legal awareness.

Consequently, the implementation of the elective course "Contemporary Seafarer's Legal Culture" into the educational process of the Institution of Professional (Vocational) Education is determined as the third pedagogical condition for the purposeful formation of the prospective proficient seafarers' legal culture.

Conclusions. For the effective formation of the prospective seafarers' legal culture in the educational process of professional (vocational) education schools, it is necessary to ensure the following conditions: the purposeful development of the students' need for professional and legal knowledge; application of innovative pedagogical technologies in professional legal training of seafarers; organization of effective students' self-educational cognitive-legal activities; implementation of the elective course "Contemporary Seafarer's Legal Culture" in the educational process of IofV(VT)E.

The prospects of further research are associated with the development of a structural model for the formation of the professional legal culture of future proficient seafarers in the professional (vocational) education schools of the marine profile.

\section{List of references}

Бусел, В. Т. ред., 2019. Великий тлумачний словник сучасної украӥнськой мови. К.: Ірпінь: ВТФ "Перун".

Гласс, Дж., Стенли, Дж., 1976. Статистические методы в педагогике и психологии. Москва: Прогресс.

Гончаренко, С. У., 1997. Український педагогічний словник : гол. ред. Світлана Головко. Київ: Либідь.

Кручек, В. А., 2003. Формування комунікативних вмінь студентів вищих аграрних навчальних закладів освіти в процесі вивчення психолого-педагогічних дисциплін. Кандидат наук. Національний аграрний університет.

Лузан, П. Г., 2004. Теоретичні і методичні основи формування навчально-пізнавальної активності студентів y вищих аграрних закладах освіти. Доктор наук. Національний аграрний університет.

Манільські поправки до Кодексу з підготовки і дипломування моряків та несення вахти (ПДНВ) 1978 року., 2012. Офіиійний вісник України, 24.

Мося, I. А., 2013. Формування самоосвітньої компетентності майбутніх кваліфікованих робітників у процесі загальноосвітньої підготовки. Кандидат наук. Інститут професійно-технічної освіти НАПН України.

International Maritime Organization: база даних Міжнародної морської організації. [online] Available at: <http:// www.imo.org/en/OurWork/HumanElement/TrainingCertification/Pages/Default.aspx> (Дата звернення 20 Квітень 2018). 


\section{Translated \& Transliterated}

Busel, V. T. red., 2019. Velykyi tlumachnyi slovnyk suchasnoi ukrainskoi movy [Great Explanatory Dictionary of Contemporary Ukrainian Language]. K.: Irpin: VTF "Perun", [in Ukrainian].

Hlass, Dzh., Stenly, Dzh., 1976. Statystycheskye metody v pedahohyke y psykholohyy [Statistical Methods in Pedagogy and Psychology]. Moskva: Prohress, [in Russian].

Honcharenko, S. U., 1997. Ukrainskyi pedahohichnyi slovnyk [Ukrainian Pedagogical Dictionary]: hol. red. Svitlana Holovko. Kyiv: Lybid, [in Ukrainian].

Kruchek, V. A., 2003. Formuvannia komunikatyvnykh vmin studentiv vyshchykh ahrarnykh navchalnykh zakladiv osvity v protsesi vyvchennia psykholoho-pedahohichnykh dystsyplin [Formation of Communicative Skills of Students of Higher Agricultural Educational Institutions in the Process of Studying Psychological and Pedagogical Disciplines]. Kandydat nauk. Natsionalnyi ahrarnyi universytet, [in Ukrainian].

Luzan, P. H., 2004. Teoretychni i metodychni osnovy formuvannia navchalno-piznavalnoi aktyvnosti studentiv u vyshchykh ahrarnykh zakladakh osvity [Theoretical and Methodological Foundations of Formation of Educational and Cognitive Activity of Students in Higher Agricultural Educational Institutions]. Doktor nauk. Natsionalnyi ahrarnyi universytet, [in Ukrainian].

Manilski popravky do Kodeksu z pidhotovky i dyplomuvannia moriakiv ta nesennia vakhty (PDNV) [Manila amendments to the Code for the Training and Certification of Seafarers and Watchkeeping (SEA)],1978 roku, 2012. Ofitsiinyi visnyk Ukrainy [Official Herald of Ukraine], 24, [in Ukrainian].

Mosia, I. A., 2013. Formuvannia samoosvitnoi kompetentnosti maibutnikh kvalifikovanykh robitnykiv u protsesi zahalnoosvitnoi pidhotovky [Formation of Self-educational Competence of future Skilled Workers in the Process of General education]. Kandydat nauk. Instytut profesiino-tekhnichnoi osvity NAPN Ukrainy, [in Ukrainian].

International Maritime Organization: Database of the International Maritime Organization. [online] Available at: $<$ http://www.imo.org/en/OurWork/HumanElement/TrainingCertification/Pages/Default.aspx> (Applying Date April 20, 2018), [in English].

\section{Основні детермінанти формування правової культури майбутніх кваліфікованих моряків}

Юлія Сжокіна,

аспірантка Інституту професійно-технічної освіти НАПН України

Реферат. У статті обгрунтовуються основні педагогічні умови цілеспрямованого формування правової культури майбутніх кваліфікованих робітників-моряків у закладах професійної (професійно-технічної) освіти (далі: ЗП(ПТ)О). Формування правової культури майбутніх робітників-моряків насамперед спрямоване на формування у них сучасних правових знань, зокрема міжнародного морського права, правосвідомості, умінь успішно розв'язувати в майбутньому професійно-правові ситуації, готовності постійно поповнювати обсяг правових знань у самоосвітній діяльності. Нині це особливо актуально для випускників закладів професійної освіти морського профілю: вітчизняне судноплавство істотно змінюється, міняються умови роботи плавскладу, зокрема й на міжнародних суднах.

Провідну ідею дослідження характеризує положення про те, що правову культуру, правосвідомість, правоповедінку, зокрема майбутніх кваліфікованих робітників-моряків, необхідно цілеспрямовано формувати, розвивати. У роботі засобами експертного оцінювання виявлено низку факторів, що найбільшою мірою впливають на формування правової культури майбутніх кваліфікованих робітників-моряків, зокрема: 1) інноваційні педагогічні технології; 2) зміст професійно-правової підготовки майбутніх робітників-моряків; 3) сучасні засоби (в тому числі IT-технології) професійно-правової підготовки; 4) інформаційно-освітнє середовище закладу професійної (професійно-технічної) освіти; 5) педагогічна інтеграція; 6) самоосвітня пізнавально-правова діяльність учня; 7) результативні методи опанування учнями правовими знаннями і вміннями; 8) професійно-педагогічна компетентність викладачів, задіяних до програми підготовки робітників-моряків; 9) досвід професійно-правової поведінки; 10) мотивація учнів в оволодінні професійно-правовими знаннями; 11) діагностика, оцінювання та управління процесом формування правової культури учнів.

За результатами факторного аналізу обгрунтовано такі основні педагогічні умови: цілеспрямоване формування потреби учнів у професійно-правових знаннях; застосування інноваційних педагогічних технологій у професійній правовій підготовці робітників-моряків; організація продуктивної самоосвітньої пізнавально-правової діяльності учнів; упровадження в освітній процес закладу професійної освіти факультативу "Правова культура сучасного моряка".

Ключові слова: професійна освіта, правова культура, майбутній кваліфікований робітник-моряк, міжнародне морське право; правосвідомість. 